\title{
Role of Phosphorus, Zinc and Rhizobium on Physico-Chemical Properties of Soil in Field Pea (Pisum sativum L.) cv. Rachna
}

\section{Prakash Dev Verma*, Narendra Swaroop, Yogesh Upadhyay, Akash Swamy and Soman Singh Dhruw}

\author{
Department of soil science, Sam Higginbottom Institute of Agriculture, Technology and \\ Sciences, Allahabad, 211007 (U.P.), India \\ *Corresponding author
}

\begin{tabular}{|c|c|}
\hline & A B S T R A C T \\
\hline & \multirow{6}{*}{ 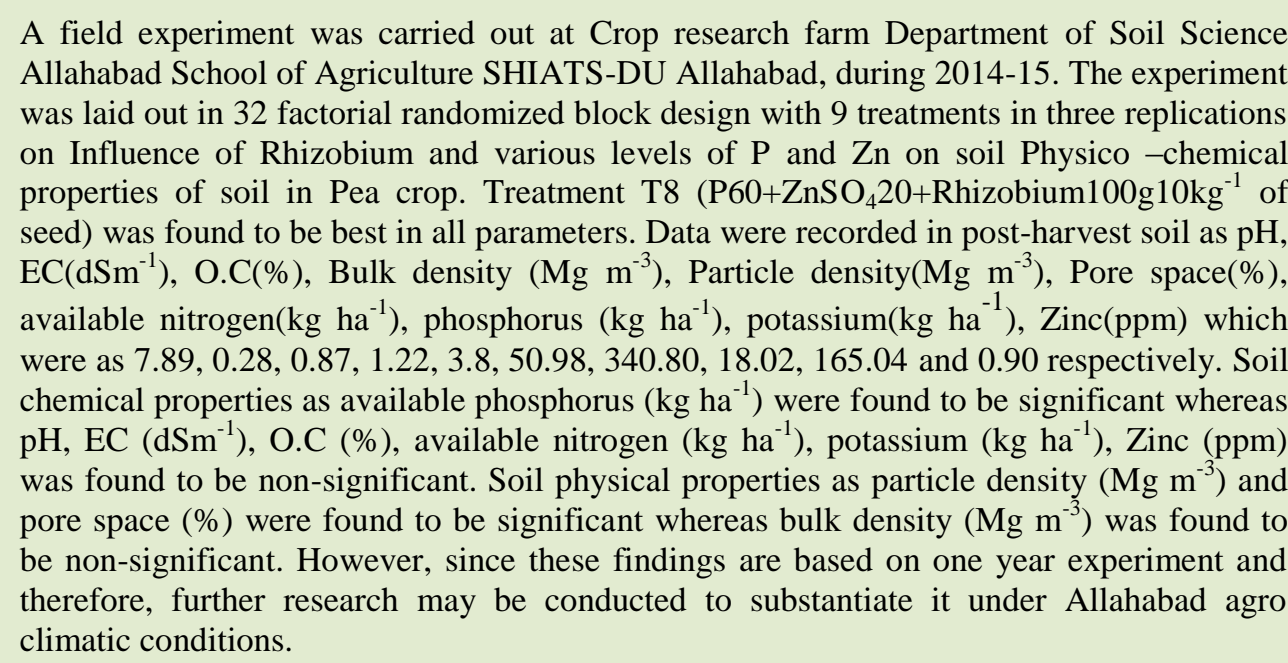 } \\
\hline Keywords & \\
\hline $\begin{array}{l}\text { Rhizobium, } \\
\text { P, Zn, Soil } \\
\text { physico-chemical } \\
\text { properties, } \\
\text { Pea. }\end{array}$ & \\
\hline Article Info & \\
\hline $\begin{array}{l}\text { Accepted: } \\
\text { 30 June } 2017 \\
\text { Available Online: } \\
\text { 10 July } 2017\end{array}$ & \\
\hline & \\
\hline
\end{tabular}

\section{Introduction}

Pea (Pisum sativum L.) is one of the important vegetables in the world and ranks among the top 10 vegetable crops. Pea is commonly used in human diet throughout the world and it is rich in protein (21-25\%), carbohydrates, vitamin $\mathrm{A}$ and $\mathrm{C}, \mathrm{Ca}$, phosphorous and has high levels of amino acids, lysine and tryptophan (Bhat et al., 2013). Its cultivation maintains soil fertility through biological nitrogen fixation in association with symbiotic rhizobium prevalent in its root nodules and thus play a vital role in fostering sustainable agriculture (Negi et al., 2006). Therefore, apart from meeting its own requirement of nitrogen, peas are known to leave behind residual nitrogen in soil 50-60 kg/ha (Kanwar et al., 1990).

Chemical fertilizers are needed to get good crop yields but their abuse and overuse can be harmful for the environment and their cost cannot make economic and profitable agricultural products (Bobade et al., 1992). The increased use of chemicals under 
intensive cultivation has not only contaminated the ground and surface water but has also distributed the harmony existing among the soil, plant and microbial population (Bahadur et al., 2006). Biofertilizers on the other hand are costeffective and renewable source of plant nutrients to supplement the parts of chemical fertilizers.

Biofertilizers are known to play an important role in increasing availability of nitrogen and phosphorus besides improving biological fixation of atmospheric nitrogen and enhance phosphorus availability to crop (Bhat et al., 2013). Therefore, introduction of efficient strains of Rhizobium in soils with low nitrogen may help augment nitrogen fixation and thereby boost production of crops. Phosphorus is known to play an important role in growth and development of the crop and have direct relation with root proliferations, straw strength, grain formation, crop maturation (Bhat et al., 2013).

Enhancing $\mathrm{P}$ availability to crop through phosphate-soubilizing bacteria (PSB) holds promise in the present scenario of escalating prices of phosphatic fertilizers and a general deficiency of $\mathrm{p}$ in Indian soils (Alaguwadi and Gaur, 1988). A judicious use of organic manures and Biofertilizers may be effective not only sustaining crop productivity and in soil health, but also in supplementing chemical fertilizers of crop (Jaipal et al., 2011).

Amongst the soil bacteria there is a unique group called rhizobia that have a beneficial effect on the growth of legumes. Once the relationship between plant and rhizobia is established, the plant supplies the rhizobia with energy from photosynthesis and the rhizobia fix atmospheric nitrogen in the nodule, converting it into from that the plant can use. Both the plant and the rhizobia benefit from such a relationship called a symbiosis (Mishra et al., 2010). Phosphorus is the second most important nutrient that must be added to the soil to maintain plant growth and sustain crop yield (Osman et al., 2011).

Nitrogen is vital nutrient for plant and crop growth. It constitutes $78 \%$ of earth's atmosphere. It occupies is applied at appropriate levels and growth periods it may substantially improve the crop productions. Nitrogen is contained in all proteins, nucleic acids and in all protoplasm.

It is taken up by the plant through its roots as ammonium or an nitrate is rapidly converted to ammonium ions which combine with carbohydrates formed during photosynthesis to form amino eventually proteins. The protein is used in the growth of the leaves and increases their green surface area, thus increasing photosynthesis and stimulating further growth. Nitrogen increases seed protein content in peas and may be correlated with improved germination and seedling vigour (Bhat et al., 2013).

\section{Materials and Methods}

The experiment was conducted during November to marchof 2014-15 at Crop research farm Department of Soil Science Allahabad School of Agriculture SHIATSDU Allahabad. The experimental site is located in the sub - tropical region with 250 $271 \mathrm{~N}$ latitude $810511 \mathrm{E}$ longitudes and 98 meter the sea level altitudes. The experiment was laid out in a $3 \neg 2$ Factorial RBD design with each three levels of Phosphorus and Zinc with nine treatments, each consisting of three replicates.

The total number of plots was 27. Field pea was sown in Rabi season plots of size 2 × 2 m with row spacing $30 \mathrm{~cm}$ and plant to plant distance $10 \mathrm{~cm}$. The Soil of experimental area falls in order of Inceptisol and is alluvial in nature, both the mechanical and chemical 
analysis of soil was done before starting of the experiment to ascertain the initial fertility status. The soil samples were randomly collected from $0-15 \mathrm{~cm}$ depths prior to tillage operations. The treatment consisted of nine combination of inorganic source of fertilizers $\mathrm{T} 0$ (Control), $\mathrm{T} 1\left(\mathrm{P} 0+\mathrm{ZnSO}_{4} 10+\right.$ Rhizobium $100 \mathrm{~g} 10 \mathrm{~kg}^{-1}$ of seed), T2 $\left(\mathrm{P} 0+\mathrm{ZnSO}_{4} 20\right.$

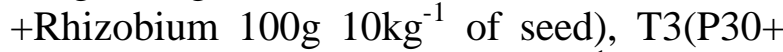
$\mathrm{ZnSO}_{4} 0+$ Rhizobium $100 \mathrm{~g} 10 \mathrm{~kg}^{-1}$ of seed), $\mathrm{T} 4\left(\mathrm{P} 30+\mathrm{ZnSO}_{4} 10+\right.$ Rhizobium $100 \mathrm{~g}_{10 \mathrm{~kg}^{-1}}$ of seed), $\mathrm{T} 5\left(\mathrm{P} 30+\mathrm{ZnSO}_{4} 20+\right.$ Rhizobium $100 \mathrm{~g}^{10 \mathrm{~kg}^{-1}}$ of seed), T6 $\left(\mathrm{P} 60+\mathrm{ZnSO}_{4} 0+\right.$ Rhizobium $100 \mathrm{~g} \quad 10 \mathrm{~kg}^{-1}$ of seed), T7 $\left(\mathrm{P}_{60}+\mathrm{ZnSO}_{4} \quad 10+\mathrm{Rhizobium} 100 \mathrm{~g} \quad 10 \mathrm{~kg}^{-1}\right.$ of seed), T8 $\left(\mathrm{P} 60+\mathrm{ZnSO}_{4} 20+\right.$ Rhizobium $100 \mathrm{~g}$ $10 \mathrm{~kg}^{-1}$ of seed). The source of Phosphorus and Zinc as SSP and Zinc sulphate respectively.

\section{Results and Discussion}

\section{Physical properties}

Response on bulk density, particle density and pore space $(\%)$ of soil after crop harvest

The result depicted in Table: 3 shows that the maximum $\mathrm{Db}$ of soil $\left(\mathrm{Mg} \mathrm{m}^{-3}\right)$, was found in
T8 which was 1.22 and minimum was found in $\mathrm{T} 0$ which was $1.17 \mathrm{Mg} \mathrm{m}^{-3}$. The interaction effect of Phosphorus and Zinc with NPK on $\mathrm{Db}\left(\mathrm{Mg} \mathrm{m}^{-3}\right)$ of soil were found nonsignificant. The results shows that the maximum Dp of soil $\left(\mathrm{Mg} \mathrm{m}^{-3}\right)$, was found in T8which was 3.80 and minimum was found in $\mathrm{T} 0$ which was $2.94 \mathrm{Mg} \mathrm{m}^{-3}$. The interaction effect of Phosphorus and Zinc with NPK on Dp $\left(\mathrm{Mg} \mathrm{m}^{-3}\right)$ of soil were found significant. The results shows that the maximum pore space (\%) of soil, was found in T8which was 50.98 and minimum was found in T0 which was 44.18. The interaction effect of Sulphur and Zinc with NPK on pore space (\%) of soil were found significant.

\section{Chemical properties}

Response on $\mathrm{pH}$ and $\mathrm{EC}$ at $25^{\circ} \mathrm{C}\left(\mathrm{dSm}^{-1}\right)$ of soil after crop harvest

The result depicted in Table: 3 shows that the maximum $\mathrm{pH}$ and $\mathrm{EC}$ of soil was found in T8which were 7.89 and 0.28 , and minimum was found in T0 which were 7.60 and 0.17 . The interaction effect of Phosphorus and Zinc with NPK on $\mathrm{pH}$ and EC was found nonsignificant.

Table.1 Physical analysis of soil

\begin{tabular}{|c|c|c|}
\hline Particulars & Method employed & Results \\
\hline Sand (\%) & Bouyoucous Hydrometer & 68.00 \\
\hline Silt (\%) & method Bouyoucous (1927) & 17.50 \\
\hline Clay (\%) & & 14.50 \\
\hline Textural class Sandy loam & \\
\hline Bulk density $\left(\mathrm{Mg} \mathrm{m}^{-3}\right)$ & Graduated measuring cylinder Black (1965) 1.63 \\
\hline Particle density $\left(\mathrm{Mg} \mathrm{m}^{-3}\right)$ & Graduated measuring cylinder Black (1965)2.69 \\
\hline Pore Space $(\%)$ & Graduated measuring cylinder Black (1965)53.22 \\
\hline
\end{tabular}


Table.2 Chemical analysis of soil

\begin{tabular}{|c|c|c|}
\hline Particulars & Method employed & Results \\
\hline $\mathrm{pH}(1: 2)$ Digital $\mathrm{pH}$ meter & (Jackson, 1958) & 7.24 \\
\hline EC $\left(\mathrm{dS} \mathrm{m}{ }^{-1}\right)$ & $\begin{array}{c}\text { EC meter (Digital Conductivity Meter) } \\
\text { (Wilcox, 1950) }\end{array}$ & 0.32 \\
\hline Organic Carbon (\%) & (Walkley and Black's method 1947) & 0.49 \\
\hline Available Nitrogen $\left(\mathrm{kg} \mathrm{ha}^{-1}\right)$ & $\begin{array}{c}\text { Alkaline potassium permanganate method } \\
\text { (Subbaih and Asija (1956) }\end{array}$ & 280.70 \\
\hline Available Phosphorus $\left(\mathrm{kg} \mathrm{ha}^{-1}\right)$ & $\begin{array}{c}\text { Colorimetric method } \\
\text { (Olsen } \text { et al., 1954) }\end{array}$ & 17.96 \\
\hline Available Potassium $\left(\mathrm{kg} \mathrm{ha}^{-1}\right)$ & $\begin{array}{c}\text { Flame photometric method } \\
\text { (Toth and Prince, 1949) }\end{array}$ & 258.00 \\
\hline Available Zinc $\left(\mathrm{kg} \mathrm{ha}^{-1}\right)$ & $\begin{array}{c}\text { Spectrophotometer } \\
\text { (Shaw and Dean1952) }\end{array}$ & 2.25 \\
\hline
\end{tabular}

Table.3 Soil properties

\begin{tabular}{|c|c|c|c|c|c|c|c|c|c|c|}
\hline Treatment & pH & $\begin{array}{l}\text { EC } \\
\left(\mathrm{dSm}^{-1}\right)\end{array}$ & $\begin{array}{l}\text { Bulk } \\
\text { density } \\
\text { (Mg m } \\
{ }^{-} \text {) }\end{array}$ & $\begin{array}{l}\text { Particle } \\
\text { density } \\
\left(\mathrm{Mg} \mathrm{m}^{-3}\right)\end{array}$ & $\begin{array}{l}\text { Pore } \\
\text { space } \\
(\%)\end{array}$ & $\begin{array}{l}\text { Organi } \\
\text { c } \\
\text { Carbon } \\
(\%)\end{array}$ & $\begin{array}{l}\text { Nitrogen } \\
\left(\mathrm{Kg} \mathrm{ha}^{-1}\right)\end{array}$ & $\begin{array}{l}\text { Phosphoro } \\
\text { us }\left(\mathrm{Kg} \mathrm{ha}^{-1}\right)\end{array}$ & $\begin{array}{l}\text { Potassiu } \\
\mathbf{m}(\mathbf{K g} \\
\left.\text { ha }^{-1}\right)\end{array}$ & $\begin{array}{c}\text { Zinc } \\
\text { (ppm) }\end{array}$ \\
\hline$T_{0}$ & 7.60 & 0.17 & 1.17 & 2.94 & 44.18 & 0.55 & 293.76 & 9.31 & 125.74 & 0.50 \\
\hline$T_{1}$ & 7.60 & 0.18 & 1.25 & 2.98 & 46.84 & 0.57 & 317.67 & 11.39 & 135.61 & 0.54 \\
\hline$T_{2}$ & 7.64 & 0.19 & 1.20 & 2.99 & 47.76 & 0.58 & 317.67 & 12.04 & 138.24 & 0.57 \\
\hline $\mathbf{T}_{3}$ & 7.66 & 0.20 & 1.20 & 3.03 & 47.78 & 0.62 & 321.53 & 13.05 & 139.16 & 0.63 \\
\hline $\mathbf{T}_{4}$ & 7.70 & 0.20 & 1.29 & 3.03 & 48.84 & 0.64 & 321.63 & 14.97 & 140.28 & 0.67 \\
\hline$T_{5}$ & 7.72 & 0.21 & 1.28 & 3.04 & 48.94 & 0.72 & 330.31 & 16.51 & 144.78 & 0.70 \\
\hline$T_{6}$ & 7.80 & 0.25 & 1.22 & 3.16 & 49.44 & 0.87 & 338.78 & 17.04 & 159.76. & 0.88 \\
\hline $\mathbf{T}_{7}$ & 7.79 & 0.22 & 1.22 & 3.07 & 49.02 & 0.74 & 335.12 & 16.66 & 149.58 & 0.83 \\
\hline $\mathbf{T}_{8}$ & 7.89 & 0.28 & 1.30 & 3.8 & 50.98 & 0.87 & 340.80 & 18.02 & 165.04 & 0.90 \\
\hline F-test & NS & NS & NS & $S$ & S & NS & NS & S & NS & NS \\
\hline S.Em. ( $( \pm)$ & 0.12 & 0.04 & 0.040 & 0.017 & 0.59 & 0.012 & 4.56 & 0.17 & 3.25 & 0.13 \\
\hline C.D. (at 5\%) & 0.26 & 0.07 & 0.085 & 0.026 & 1.25 & 0.020 & 9.67 & 0.51 & 6.89 & 0.20 \\
\hline
\end{tabular}

Response of organic carbon (\%), available nitrogen, phosphorus, potassium, $\left(\mathrm{kg} \mathrm{ha}^{-1}\right)$ of soil and Zinc (ppm) after crop harvest

The result depicted in Table: 3 shows that the maximum \% OC of soil was found in T8which was 0.87 and minimum was found in T0 which was 0.55 . The interaction effect of Phosphorus and Zinc with NPK on \% OC of soil was found non-significant. The available nitrogen $\left(\mathrm{kg} \mathrm{ha}^{-1}\right)$, phosphorus ( $\mathrm{kg}$ $\left.\mathrm{ha}^{-1}\right)$, potassium, $\left(\mathrm{kg} \mathrm{ha}^{-1}\right)$ and Zinc in (ppm) in soil were found maximum in T8which were 340.80, 18.02, 165.04, $0.90 \quad \mathrm{~kg} \mathrm{ha}^{-1}$ respectively and minimum was found in to which were $293.76,9.31,125.74,0.50 \mathrm{~kg} \mathrm{ha}^{-1}$ respectively.

The interaction effect of Phosphorus and Zinc with NPK on available nitrogen and 
potassium were found significant and the interaction effect of Phosphorus and Zinc with NPK on available phosphorus, and zinc was found non-significant. Combined application of Sulphur and Zinc NPK brings significantly increase in available Nitrogen and Potassium. The results are conformity with the finding of Khambalkaret al., (2012).

It is concluded that Treatment $\mathrm{T} 8$ $\left(\mathrm{P} 60+\mathrm{ZnSO}_{4} 20+\mathrm{Rhizobium} 100 \mathrm{~g} 10 \mathrm{~kg}^{-1}\right.$ of seed) was found to be best in all parameters. Data were recorded in post-harvest soil as $\mathrm{pH}$, $\mathrm{EC}\left(\mathrm{dSm}^{-1}\right)$, O.C $(\%)$, Bulk density $\left(\mathrm{Mg} \mathrm{cm}^{-3}\right)$, Particle density $\left(\mathrm{Mg} \mathrm{cm}^{-3}\right)$, Pore space $(\%)$, available nitrogen $\left(\mathrm{kg} \mathrm{ha}^{-1}\right)$, phosphorus $(\mathrm{kg}$ $\left.\mathrm{ha}^{-1}\right)$, potassium $\left(\mathrm{kg} \mathrm{ha}^{-1}\right)$, Zinc(ppm) which were as $7.89,0.28,0.87,1.22,3.8,50.98$, $340.80,18.02,165.04 \& 0.90$ respectively. Soil chemical properties as available phosphorus $\left(\mathrm{kg} \mathrm{ha}{ }^{-1}\right)$ was found to be significant whereas $\mathrm{pH}, \mathrm{EC}\left(\mathrm{dSm}^{-1}\right)$, O.C (\%), available nitrogen $\left(\mathrm{kg} \mathrm{ha}^{-1}\right)$, potassium $(\mathrm{kg} \mathrm{ha}$ ${ }^{1}$ ), Zinc (ppm) was found to be nonsignificant. Soil physical properties as particle density $\left(\mathrm{Mg} \mathrm{m}^{-3}\right)$ and pore space $(\%)$ were found to be significant whereas bulk density $\left(\mathrm{Mg} \mathrm{m}^{-3}\right)$ was found to be non-significant. However, since these findings are based on one year experiment and therefore, further research may be conducted to substantiate it under Allahabad agro climatic conditions.

\section{Acknowledgements}

The Authors are thankful to Department of Soil Science, SHIATS, Allahabad School of Agriculture, for taking their keep interest and encouragement to carry out the research work.

\section{References}

Anonymous 2010.Annual report all India coordinated pearlmillet, improvement project, 141-142.

Anonymous 2014 USDA
Anonymous 2011-12 Indian MART Inter Mesh Ltd

Anonymous 2010-11 Ministry of Agricultural, Government of India.

Ahmed, T.H.M., Elhassan, G.A., Abdelgani, M.E. and Abdalla, A.S. 2011. Effect of Rhizobium and Bacillus strains on the growth, syumbiotic properties and nitrogen and phosphorus content of lablab (Lablab purpureus L.). Advance in Envrionmental Biology, 5(1): 24-30.

Alagawadi, A.R. and Gaur, A.C.1988. Associative effect of Rhizobium and PSB on yield and nutrient uptake by chickpea, Plant and soil, 105: 241-246.

Ashraf, M.I., Pervez, M.A., Amjad, M., Ahmad, R. and Ayub M. 2011. Qualitative and quantitative response of pea (Pisumsativum L.) cultivars to judicious applications of irrigation with phosphorus and potassium.Pak. J. life soc. Sci., 9(2): 159-164.

Bhat, T.A., Gupta, M., Ganai, M.A., Ahanger, R.A. and Bhat. H.A. 2013. Yield, soil health and nutrient utilization offield pea (PisumsativumL.) as affected byphosphorus and Biofertilizers under subtropicalconditions of Jammu, International journal ofmodern plant and animal science, 1(1):1-8.

Bobade K.P., Kolte S.O., Patil B.G. 1992. Affectivity of cyanobacterial technology for transplanted rice, Phykos, 31: 33-35.

Dashadi, M., Hossein, A., Radjabi, R. and Babainejad, T. 2013 Investigation of effect different rates phosphorus and Zinc fertilizers on two cultivars Lentil Gachsaran and Flip 92-12L in irrigation complement condition. International Journal of Agriculture and Crop Sciences IJACS/2013/5-1/1-5.

Jaipaul, Sharma, S., Dixit, A.K. and Sharma A.K. 2011. Growth and yield of capsicum and garden pea as influenced 
by organic manures and biofertilizers, Indian J. ofAgricultural Sciences 81(7): 637-642.

Milivojevic, J., Nikezic, D., Krstic, D., Jelic, M. and Ivica D. 2011. Influence physical chemical characteristics of soil on zinc distribution and availability for plants in vertisols of Serbia. Polish J. of Environ. Vol. 20, No. 4: 993-1000.

Lalitha, S. and Santhaguru, K. 2012. Improving soil physical properties and effect on tree legume seedlings growth under barren soil. Agricultural Science Research Journal. Vol. 2(3), pp. 126130.

Kanwar JS 1990 Punjab Veg. Grower, 25: 1215.

Khanday, A.B.S., Sharma, U., Dubey. P.K and Bhardawaj, S.B. 2012. Effect of Different fertilizer and irrigation Management System on soil physicochemical properties and pod yield of Garden Pea (PisumSativum L.). International Journal of Food, Agriculture and Veterinary Sciences ISSN: 2277-209 X 2012 Vol. 2(3): 15516.

Mishra,K., Prasad, K. and GeetaRai. 2010. Effect of bio-fertilizer inoculation on growth and yield of dwarf field pea
(Pisumsativum L.) in Conjunction with different Doses on Chemical Fertilizers. Journal of Agronomy, 9: 163-168.

Negi S, Sing RV and Dwivedi O.K. 2006. Effect of Biofertilizers, nutrient sources and lime on growth and yield of garden pea, Legume research, 29 (4): 282-285.

Oyopadhyay and Elamathi, 2007. Response of $\mathrm{N}$, levels and Rhizobium inoculation on yield, uptake of nutrients uptake by black gram (Vignamungo L.) rainfedconditons. Research on crops: 4:1, pp 39-43.

Quddus, M.A., Rashid, M.H., Hossain, M.A. and Naser, H.M. 2011. Effect of zinc and boroan on yield and yield contributing charactes of mungbean in low ganges river floodplaion soil at madaripur. Bangladesh ISSN 02587122 Bangladesh J. Agricl. Res. 36(1): 75-85, March 2011.

Sepehya, S., Bhardwaj, S.K., Dixit, S.P. and Dhiman S. 2012. Effect of integrated nutrient management on yield attributes, yield and NPK uptake in garden pea (Pisumsativum L) in acid Alfisol, Journal of Food Legumes 25(3): 247$249,2012$.

\section{How to cite this article:}

Prakash Dev Verma, Narendra Swaroop, Yogesh Upadhyay, Akash Swamy and Soman Singh Dhruw. 2017. Role of Phosphorus, Zinc and Rhizobium on Physico-Chemical Properties of Soil in Field Pea (Pisum sativum L.) Cv. Rachna. Int.J.Curr.Microbiol.App.Sci. 6(7): 44234428. doi: https://doi.org/10.20546/ijcmas.2017.607.461 